\title{
Modern tesztelméleti eszközök alkalmazása az ápolók transzfúziós ismereteinek objektív mérésében
}

\author{
Rajki Veronika ${ }^{1,3}$. Deutsch Tibor dr. ${ }^{2}$ - Csóka Mária ${ }^{1}$ - Mészáros Judit dr. ${ }^{4}$ \\ Semmelweis Egyetem, Egészségtudományi Kar, ${ }^{1}$ Alkalmazott Egészségtudományi Intézet, Ápolástan Tanszék, \\ ${ }^{2}$ Képalkotó Diagnosztikai Analitikus és Orvostechnikai Tanszék, Budapest \\ ${ }^{3}$ Semmelweis Egyetem, Doktori Iskola, Budapest \\ ${ }^{4}$ Semmelweis Egyetem, Egészségtudományi Kar, Alkalmazott Egészségtudományi Intézet, Budapest
}

\begin{abstract}
Bevezetés: Az egészségügyi hivatás gyakorlása során a szakdolgozóknak a megszerzett ismereteket különféle feladatok és problémák megoldásában kell alkalmazni. Ezért az oktatás eredményességének megítéléséhez a különböző tudáselemek - ismeretek, készségek és kompetenciák - objektív és megbízható mérésére van szükség. A hagyományos kérdőívek és tesztek segítségével általában a szakdolgozók összteljesítményét határozzák meg, ami azonban korántsem ad teljes képet a valódi tudás- és képességszintról. Célkitüzés: Az ápolók körében 2014. november és 2015. február között elvégzett országos felmérés célja annak megállapítása volt, hogy a képzési célok milyen mértékben valósultak meg az ápolók transzfuziológiai gyakorlatában. A szerzők arra törekedtek, hogy meghaladják a klasszikus tesztek korlátait, és részleteiben is elemezzék az ápolók transzfúziós szakmai ismereteit. Módszer: Az ápolók ismereteinek objektív mérése saját készítésű validált kérdőívvel történt. Az országos reprezentatív felmérésben 657 személy vett részt. A transzfúziós gyakorlat valamennyi aspektusát felölelő kérdéssor egyes itemeire adott válaszokat bináris (jó/rossz) skálán értékelték. A kapott adatokat hierarchikus klaszterelemzéssel és a dichotóm adatok elemzésére alkalmas egyparaméteres Rasch-modell (item response theory - IRT-eljárás) segítségével elemezték. Az adatok feldolgozását az SPSS program és az R statisztikai program ltm moduljával végezték. Eredmények: A szerzők meghatározták a transzfúziós terápiával kapcsolatos kérdésekre kapott helyes és hibás válaszok megoszlását, továbbá a kapcsolódó logit- és esélyhányados-értékeket. A Rasch-modell alapján elkészítették az egyes tudáselemekre vonatkozó úgynevezett karakterisztikus görbéket, amelyek az egyes itemek nehézségi fokát tükrözik. Képet kaptak arról, hogy az ápolók mely kérdéseket válaszolták meg könnyen, melyek okoztak nagyobb nehézséget, továbbá arról is, hogy mely kérdéskombinációkra tudták jellemzően sokan a helyes válaszokat. Az ápolók összességében közepes vagy annál gyengébb teljesítményt nyújtottak. Következtetések: A tudásszint objektív mérése az ápolástan-oktatásban is kulcsfontosságú. A korszerú valószínúségi tesztelméleten alapuló tudásszintmérő módszereket a szerzók elsőként alkalmazták ezen a szakterületen, ezért a jelen felmérést a szerzők hiánypótlónak tekintik és figyelemfelhívásnak szánják. A valószínúségi módszerekkel végzett kutatás egyértelmúen bizonyította, hogy jelentős hiányosságok találhatók az ápolók transzfuziológiai ismereteiben, ezért folyamatos továbbképzésekre van szükség. Orv. Hetil., 2015, 156(37), 1497-1508.
\end{abstract}

Kulcsszavak: modern tesztelmélet, tudásszintmérés, klaszteranalízis, Rasch-modell, transzfúziós terápia, vérbiztonság

\section{Objective assessment of transfusion-related knowledge of nurses using modern test theory}

Introduction: Clinical practice requires knowledge of health professionals for the application of problem solving of different tasks in various clinical settings. Therefore, a set of reliable measurement tools is required to assess various components of the professional knowledge including factual knowledge, skills and competence as outcomes of nursing education and training. Traditional questionnaires and test methods do not allow the measurement of these characteristics properly, as these tools typically provide overall scores without relevant insight into areas in which nurses perform well, and those where their knowledge and/or skills should be improved substantially. Aim: The aim of this nationwide survey conducted among nurses between November 2014 and February 2015 was to determine how the teaching/training objectives have been achieved in the nurses' transfusion practice. The authors attempted to exceed the capabilities of classical test theory and acquire a detailed picture about what the nurses know about 
transfusion therapy and how they are involved and behave in routine clinical practice. Method: The knowledge and skills of 657 participants were assessed using a validated instrument consisting of a set of questions covering every aspects of transfusion therapy. The answers to these items were evaluated on a binary (good or bad) scale. Recorded answers of the participants were analysed using hierarchical cluster analysis and item response theory tools such as the one-parametric Rasch model suitable for dichotomous data. Data analysis was performed with the SPSS program and the ltm module of the R statistical program. Results: The paper presents the distribution of correct and incorrect answers to various questions about transfusion therapy along with the corresponding logit values and odds ratios, respectively. The characteristic curves of each item were determined on the basis of the number of correct answers that have been recorded. These curves highlight which questions were answered easily and which items were found harder to answer by the nurses who participated in the survey. In addition to the separate analysis of individual questions, a set of response patterns is also presented which shows how frequently the nurses responded correctly to different combinations (sub-sets) of questions. On the whole, nurses exhibited medium level performance in terms of knowledge and skills required for efficient and safe transfusion practice. Conclusions: Objective and reliable measurement of the level of acquired knowledge is a key requirement in nursing education. This paper, which demonstrates the use of cluster analysis and item response theory for the assessment of transfusion-related knowledge of nurses, focuses on this issue for the first time in nursing research. The results of this survey have revealed substantial limitations and deficiencies both in knowledge and skills of nurses which need to be addressed by training in order to improve the efficiency and safety of transfusion therapy.

Keywords: modern test theory, knowledge measurement, cluster analysis, Rasch model, transfusion therapy, blood safety

Rajki, V., Deutsch, T., Csóka, M., Mészáros, J. [Objective assessment of transfusion-related knowledge of nurses using modern test theory]. Orv. Hetil., 2015, 156(37), 1497-1508.

(Beérkezett: 2015. június 10.; elfogadva: 2015. július 16.)

\section{Rövidítések}

$\mathrm{CI}=($ confidence interval $)$ megbízhatósági/konfidencia intervallum; ikl-ikll = transzfúziós terápiával kapcsolatos ismeretek jelölése; IRT $=$ (item response theory) a valószínüségi (modern) tesztelmélet; kkl-kkl6 = transzfúziós terápiával kapcsolatos ápolási kompetenciákra vonatkozó ismeretek

Az egészségügyi hivatás gyakorlása során a szakdolgozóknak a megszerzett ismereteket különféle feladatok és problémák megoldásában kell alkalmazni. Ezért az oktatás eredményességének megítéléséhez a különbözó tudáselemek - ismeretek, készségek és kompetenciák objektív és megbízható mérésére van szükség. A hagyományos kérdőívek és tesztek segítségével általában a szakdolgozók összteljesítményét határozzák meg, ami azonban korántsem ad teljes képet a valódi tudás- és képességszintról.

\section{Módszer}

Az ápolók körében 2014. november 19. és 2015. február 20. közötti intervallumban országos felmérést végeztünk annak megállapítására, hogy a képzési célok milyen mértékben valósultak meg az ápolók transzfuziológiai gyakorlatában. Kutatásunkhoz országos reprezentatív mintát $(\mathrm{n}=657$ fó) választottunk, és a válaszadók tudásszintjét kritériumorientált tesztelés alapján értékel- tük. A viszonyítás alapját a jelenleg érvényes transzfúziós tevékenységet meghatározó Transzfúziós Szabályzat (2014) elóírásainak ismerete [1], valamint az ápolók szakmai, jogi és etikai kompetenciái képezték.

A felmérésnél alkalmazott saját készítésû tudásszintmérő eszköz validálásáról és megbízhatóságának vizsgálatáról korábban már beszámoltunk. A primer-kvantitatív keresztmetszeti kutatás adatait első lépésben leíró és matematikai statisztikai eljárások segítségével dolgoztuk fel.

A modern tesztelméleti módszerek és klaszteranalízis segítségével mélyebb betekintést kaphatunk az ápolók szakmai ismereteiről és attitúdjéről. Jelen tanulmányunkban az országos felmérés adatait az item response theory (IRT) és a klaszteranalízis szemüvegén keresztül elemezzük. A közleményben a szakmailag releváns eredményekre és következtetésekre fokuszálunk, a felhasznált módszerekről és a hátterükben meghúzódó valószínűségi modellekről csak az eredmények értelmezéséhez szükséges mértékben esik szó.

\section{A klasszikus tesztelmélet}

Az egészségügyi hivatás gyakorlása általában nem a tudás szóbeli vagy írásbeli reprodukcióját várja el a szakdolgozóktól, hanem az ismeretek gyakorlati alkalmazását a különféle feladatok, problémák megoldásában a betegellátás különböző helyzeteiben [2]. Az oktatás eredmé- 
nyességének, vagyis a különböző tudáselemek - ismeretek, készségek és kompetenciák - mérésének egyik leggyakrabban alkalmazott formája a tudásszintmérés [3]. A különböző tudásszintmérő tesztek a meghatározott tananyag elsajátításának szintjét, az ismeretek alkalmazásához szükséges készségek, képességek fejlődésének értékelését teszik lehetővé [4]. A képzés során minden oktató elkészíti a saját tesztjét, amelyet az általa oktatott tantárgy célja és a képzési követelményeknek megfelelő tananyagtartalom alapján állít össze. A tesztszerkesztés lényege, hogy a tananyagból olyan kis feladatelemeket (itemeket) készítünk, amelyeket önállóan értékelünk. Könnyen megállapítható, hogy a lehetséges összpontszámból ki hány pontot ért el, vagyis milyen szinten sajátította el a tananyagot, továbbá, hogy a válaszadók hány százaléka tartozik a jobb és hány a roszszabb képességű kategóriába, tehát alkalmas a szelektálásra is. A félévközi és a záró, szummatív értékeléshez egyaránt rutinszerúen használjuk, mivel a képzési folyamat bármely időpontjában gyorsan elvégezhető, és megbízhatóan mér [5].

\section{Az objektiv mérés megvalósulásának lehetösége}

Az ápolók életpálya-követése, munkahelyi beválóságának objektív vizsgálata kulcsfontosságú kérdés az oktatók számára, de az eredmények reális értékelése a hagyományos kérdőívek segítségével kétséges. A hosszúság, tömeg, idő mérésére olyan hiteles mérőeszközök szolgálnak, amelyek objektív mérésre alkalmasak. A tudás méréséhez azonban nem rendelkezünk hasonló, objektív mérőeszközökkel, hiszen a tanári osztályzatok szubjektívek, ezért a kapott jegy értékéből nem következtethetünk a tényleges tudásra. Egy univerzális tudásskála létrehozásához pontosan kellene tudnunk, hogy kinek milyen a tudásszintje az elvárható optimális teljesítményhez viszonyítva, a szokásos teszteknél azonban csak a személyek által elért nyers pontokat vagy a százalékos összteljesítményt tudjuk összehasonlítani egymással [6]. Ez azonban korántsem ad teljes képet a személyek valódi tudás- és képességszintjéról.

A valószínúségi tesztelmélet (item response theory IRT) a klasszikus elmélet korlátait igyekszik kiküszöbölni azzal, hogy nem csupán összességében, hanem részleteiben (itemenként) is elemzi a személyek teljesítményét. Az azonos összpontszámot elérő személyek tudásprofiljai ugyanis lényegesen eltérhetnek egymástól attól függően, hogy mely kérdéseket, kérdéscsoportokat válaszolták meg helyesen. Az egyes itemek nehézségi foka sem egyenlő, a könnyü kérdéseket sokan, a nehéz feladatokat azonban csak kevesen tudják helyesen megoldani. A modern tesztelmélet szerint annak a valószínúsége, hogy valaki egy adott feladatot helyesen old meg, egyrészt az illető általános tudásától, másrészt az adott kérdés/feladat nehézségétől függ. Ezt az összefüggést az egyes itemek úgynevezett karakterisztikus görbéi írják le. Ezek a görbék azt ábrázolják, hogy a válaszadó tudásszintjének növekedésével párhuzamosan miként nő annak a valószínúsége, hogy az adott itemet helyesen oldja meg $[7,8$, $9,10]$.

Gyakran az egyes itemek megoldását bináris skálán (0: rossz, 1: jó válasz) értékeljük. Az ilyen dichotóm adatok elemzésére alkalmas a Rasch-modell [9, 10], amelylyel első lépésben meghatározzuk a diákok teszten elért összpontszámát, majd elkészítjük a válaszolók személyés a tesztkérdések itemtérképét. A térkép alapján nemcsak az egyes kérdések/feladatok nehézségi fokát (könynyebb-nehezebb), hanem a válaszadók képességét (jobb-rosszabb) is megadhatjuk. Az itemekre vonatkoztatva ez a mutató az item nehézségi indexe, míg az emberekre nézve a személy képességparamétere. A képességmutatók és itemnehezségi mutatók nagyságát közös skálán (logit) mérjük. Ebből adódik, hogy a képességparaméter és az item nehézségi mutató különbsége a helyes válasz esélyének (odds) természetes alapú logaritmusa. A Rasch-modellben az item nehézségét az a képességszint méri, amelynél az adott személy a $\mathrm{p}=0,5$ valószínúséggel oldja meg helyesen az adott feladatot.

A továbbiakban a Rasch-modell gyakorlati alkalmazását mutatjuk be az országos tudásszintfelmérés adatai alapján. Az értékeléseket az $\mathrm{R}$ programcsalád ltm program moduljával végeztük.

\section{Eredmények}

\section{Transzfúziós terápiával kapcsolatos ismeretek (ikl-ikl1) elemzése}

A transzfúziós terápiával kapcsolatos ismeretekre vonatkozó kérdéseket az ikl-ikll közötti kérdésazonosítókkal jelöltük (1. táblázat).

A kvantitatív adatelemzés során a változókat dichotóm változóként kezeltük, a helyes válasz 1 , a helytelen válasz 0 pontot ért. A 2. táblázat szemlélteti a transzfúziós terápiával kapcsolatos ismeretek felmérésére irányuló kérdéseinkre kapott helyes és hibás válaszok megoszlását, továbbá az ezekből számított logit- és esélyhányados-értékeket. A táblázatból látszik, hogy a legmagasabb arányban az ik6 kérdésre $(92,24 \%)$, valamint az ikl kérdésre $(90,41 \%)$ válaszoltak helyesen. Helytelen válasz az ik8 kérdés esetében fordult elő a legnagyobb arányban $(87,06 \%)$, de nem sokkal kedvezóbb a kép az ik10 kérdés esetében sem $(74,28 \%$ hibás válasz). A táblázatban szereplö logitértékek a helyes és téves válaszok arányának logaritmusát jelölik, negatív logit esetén a hibás válaszok száma meghaladta a helyesen válaszolók számát. A táblázat utolsó oszlopában feltüntettük az esélyhányadosok értékét valamennyi kérdés esetében. Az esélyhányados a helyesen és tévesen válaszolók arányát fejezi ki.

A 3. táblázatban az egyes itemek nehézségi mutatóit tüntettük fel. A modell a nehézségi mutatókat a logitskálán fejezi ki, az értékek -5 és 5 között változnak. Az erősen negatív mutató azt jelzi, hogy az adott item megválaszolása túl könnyü, a 2,5-3 feletti itemet a válaszadók 
1. táblázat

A transzfúziós terápiával kapcsolatos ismeretek felmérésére használt kérdések azonosítói

\begin{tabular}{|c|c|}
\hline Kérdések & Kérdésazonosítók \\
\hline $\begin{array}{l}\text { Ismeretei szerint tartalmaz-e a Transzfúziós } \\
\text { szabályzat betegfelvilágosítási és -hozzájárulási } \\
\text { nyilatkozatmintát? }\end{array}$ & ikl \\
\hline $\begin{array}{l}\text { Az elózetes laboratóriumi vércsoport-szerológiai } \\
\text { vizsgálathoz milyen vérminta alkalmas, milyen } \\
\text { csövekben venne vért erre a célra? }\end{array}$ & $\mathrm{ik} 2$ \\
\hline $\begin{array}{l}\text { A vérkészítményeknek a beadást megelőzően } \\
\text { milyen hőmérséklethatárok között kell lennie? }\end{array}$ & $\mathrm{ik} 3$ \\
\hline $\begin{array}{l}\text { Ismeretei szerint a felmelegített vérkészítmények } \\
\text { beadását mikor kell megkezdeni? }\end{array}$ & $\mathrm{ik} 4$ \\
\hline $\begin{array}{l}\text { Ismeretei szerint mit jelent a „Transzfúzió előtti } \\
\text { vérminta”? }\end{array}$ & $\mathrm{ik} 5$ \\
\hline $\begin{array}{l}\text { Ismeretei szerint a klinikai } \mathrm{AB} 0 \text { - és } \mathrm{RhD} \text { - } \\
\text { vércsoport-meghatározás kötelező-e választott } \\
\text { vér beadása előtt is? }\end{array}$ & ik6 \\
\hline $\begin{array}{l}\text { Ismeretei szerint melyik a helyes válasz a klinikai } \\
\text { vércsoport-meghatározással kapcsolatban? }\end{array}$ & $\mathrm{ik} 7$ \\
\hline $\begin{array}{l}\text { Transzfúzió előtt a vércsoport-szerológiai } \\
\text { vizsgálatokon kívül a beteg állapotának és a } \\
\text { transzfúziós indikációnak megfelelően mely } \\
\text { vizsgálatokat szükséges elvégezni? }\end{array}$ & ik8 \\
\hline Melyik állítás igaz a vérkészítmények beadásánál? & ik9 \\
\hline Melyik állítás igaz a „biológiai próbára”? & $\mathrm{ik} 10$ \\
\hline Melyek a transzfúziós terápiát követő teendők? & ikl1 \\
\hline
\end{tabular}

2. táblázat |A helyes és a helytelen válaszok aránya transzfúziós terápiával kapcsolatos ismeretek esetében

\begin{tabular}{lllll}
\hline $\begin{array}{l}\text { A kérdés } \\
\text { száma }\end{array}$ & $\begin{array}{l}\text { Helytelen } \\
\text { válaszok } \\
\text { aránya }(0)\end{array}$ & $\begin{array}{l}\text { Helyes } \\
\text { válaszok } \\
\text { aránya }(1)\end{array}$ & Logit & $\begin{array}{l}\text { Esély- } \\
\text { hányados }\end{array}$ \\
\hline ik1 & 0,0959 & 0,9041 & 2,2437 & 9 \\
ik2 & 0,4262 & 0,5738 & 0,2975 & 1,35 \\
ik3 & 0,6545 & 0,3455 & $-0,6388$ & 0,53 \\
ik4 & 0,3242 & 0,6758 & 0,7345 & 2,08 \\
ik5 & 0,6819 & 0,3181 & $-0,7625$ & 0,47 \\
ik6 & 0,0776 & 0,9224 & 2,4751 & 11,88 \\
ik7 & 0.6758 & 0,3242 & $-0,7345$ & 0,48 \\
ik8 & 0,8706 & 0,1294 & $-1,9065$ & 0,15 \\
ik9 & 0,1355 & 0,8645 & 1,8535 & 6,38 \\
ik10 & 0,7428 & 0,2572 & $-1,0604$ & 0,35 \\
ik11 & 0,7108 & 0,2892 & $-0,8993$ & 0,41 \\
\hline
\end{tabular}

nehéznek találták. A negatív értékek tehát könnyü kérdéseket jelölnek, míg a pozitív logitértékek azokat a kérdéseket jelzik, amelyekre kevesen tudták a helyes választ. A kapott eredményeinkből látható, hogy az ik6 kérdés, valamint az ikl kérdés megválaszolása okozta a legkisebb problémát az ápolóknak, tehát ez a két item volt a legkönyebb. Míg az ik8 és $i k 10$ kérdések megválaszolása okoz-
3. táblázat $\mid$ Az egyes itemek nehézségi mutatói az ismeretekre vonatkozó kérdések esetében

\begin{tabular}{lccc}
\hline Item & Becsült érték & Alsó CI & Felsó CI \\
\hline ik1 & $-2,216$ & $-2,463$ & $-1,968$ \\
ik2 & $-0,210$ & $-0,367$ & $-0,052$ \\
ik3 & 0,808 & 0,641 & 0,975 \\
ik4 & $-0,668$ & $-0,832$ & $-0,504$ \\
ik5 & 0,947 & 0,777 & 1,118 \\
ik6 & $-2,452$ & $-2,723$ & $-2,181$ \\
ik7 & 0,916 & 0,746 & 1,085 \\
ik8 & 2,302 & 2,059 & 2,544 \\
ik9 & $-1,818$ & $-2,034$ & $-1,603$ \\
ik10 & 1,288 & 1,105 & 1,471 \\
ik11 & 1,103 & 0,927 & 1,278 \\
\hline
\end{tabular}

$\mathrm{CI}=($ confidence interval) megbízhatósági/konfidencia intervallum.

ta a legnagyobb problémát, tehát ez a két item volt a legnehezebb.

Az 1. ábrán az egyes itemek karakterisztikus görbéjét tüntetjük fel az egyparaméteres Rasch-modell alapján. A vízszintes tengelyen a válaszolók tudásszintje szerepel logitegységekben kifejezve. A -4 érték esetén az ápoló egyetlen kérdésre sem tudott válaszolni, a +4 logit a tökéletes ismeretekkel rendelkező ápolókat jelzi. A különböző itemek görbéi az egyszerú Rasch-modell feltételezésének megfelelően párhuzamosan futnak [6], azaz csak a vízszintes tengely mentén vannak eltolva egymáshoz képest [11]. Az ábrából kitúnik, hogy egy adott tudásszint (latent dimension) mellett az 1., a 6. és a 9. itemekre születik a legnagyobb valószínűséggel helyes válasz, míg a helyes válasz valószínúsége a 8 . item esetében a legalacsonyabb.

Vizsgáltuk továbbá azt is, hogy a transzfúziós terápiával kapcsolatos ismeretek feltérképezésére feltett 11 kérdés közül hány kérdésre tudtak helyes választ adni a megkérdezett ápolók (4. táblázat). A kapott eredményeinkből látható, hogy csupán egy résztvevő válaszolt roszszul valamennyi kérdésre, a többség négy (129fö), öt (161 fó) vagy hat (153 fó) kérdésre tudta a helyes választ. A kérdő́ivet csupán 15 résztvevő töltötte ki hibátlanul a 657 fös mintából.

A 2. ábra azt szemlélteti, hogy a különböző kérdésekre hány százalékban válaszoltak helyesen, a helyesen megválaszolt kérdések számának függvényében. A hibátlanul teljesítők összpontszáma $=11$ nem szerepel az ábrán, hiszen itt valamennyi (ikl-ikll) válasz helyes. Az ábrán jól látszik, hogy a helyesen megválaszolt kérdések összes számától függetlenül az ik6-os kérdésre (Ismeretei szerint a klinikai ABO- és RhD-pércsoport-meghatározás kötelezố-e választott vér beadása elött is?) születtek legmagasabb arányban helyes válaszok. Akik 1 kérdésre tudták a helyes választ, azok 30\%-a válaszolt erre a kérdésre helyesen, míg akik 2 kérdésre tudtak helyesen válaszolni, 


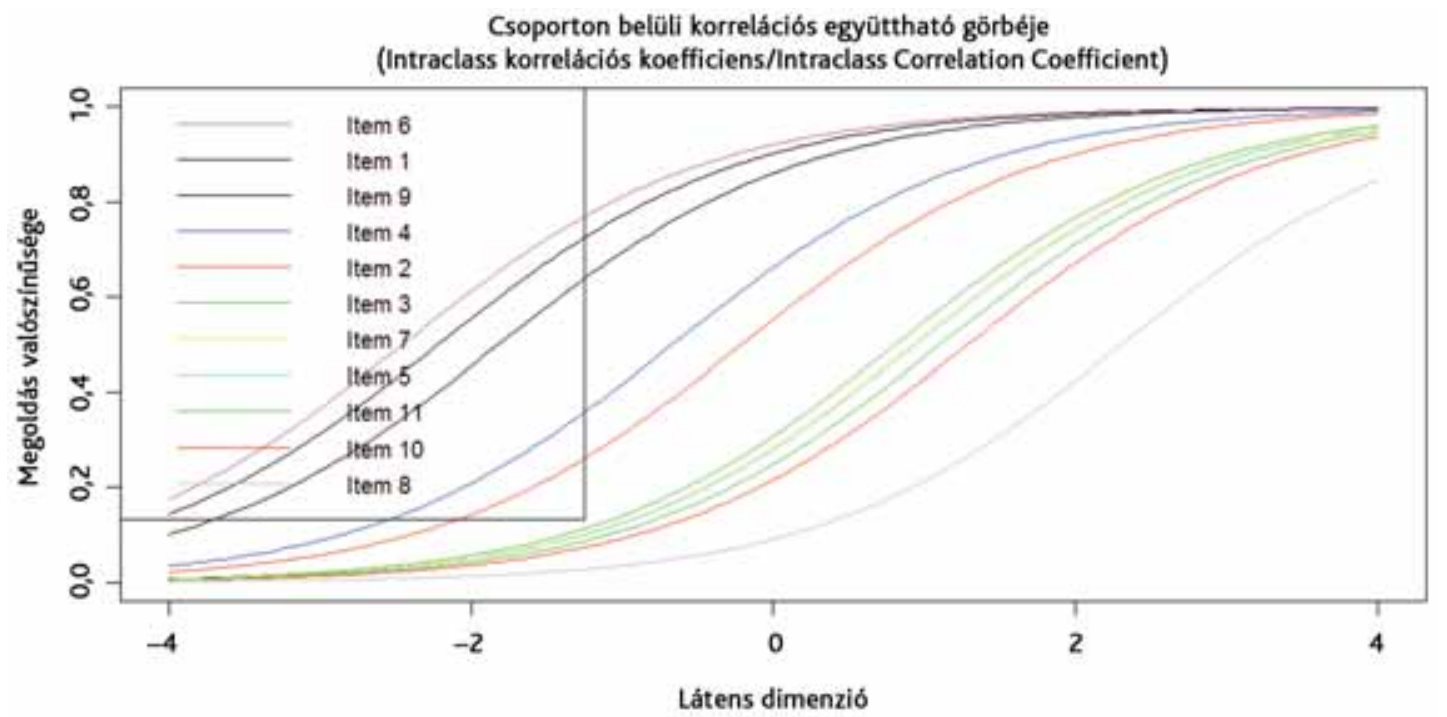

1. ábra

| Itemek karakterisztikus görbéje az egyparaméteres Rasch-modell alapján az ismeretekre vonatkozó kérdések esetében

4. táblázat |A helyes választ adók száma kérdésszámonként

\begin{tabular}{|c|c|c|c|c|c|c|c|c|c|c|c|c|}
\hline \multicolumn{13}{|c|}{ A gyakoriság összesített pontszáma } \\
\hline $\begin{array}{l}\text { Helyesen megválaszolt } \\
\text { kérdések darabszáma }\end{array}$ & 0 & 1 & 2 & 3 & 4 & 5 & 6 & 7 & 8 & 9 & 10 & 11 \\
\hline $\begin{array}{l}\text { Helyes választ adók } \\
\text { száma }\end{array}$ & $1 f^{\prime \prime \prime}$ & 0 fó & 10 fö & 43 fó & 129 fö & 161 fó & 153 fó & 83 fó & 23 fó & 26 fó & 13 fó & $15 f^{\prime \prime}$ \\
\hline
\end{tabular}

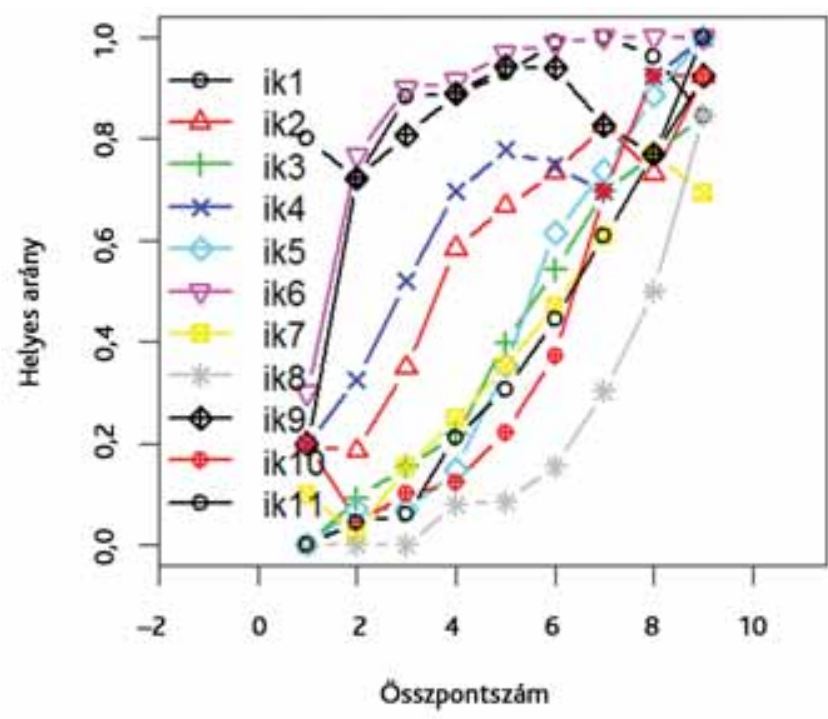

2. ábra A helyes válaszok megoszlása kérdésenként a helyesen megvála
szolt kérdések számának függvényében

azok közel $80 \%$-a tudta a helyes választ az ik6 kérdésre. A legrosszabb eredmény az $i k 8$ kérdéssel kapcsolatban (Transzfúzió elött a vércsoport-szerológiai vizsgálatokon kivül a beteg állapotának és a transzfúziós indikációnak megfelelóen mely vizsgálatokat szükséges elvégezni?) született, az 1 vagy 2 , esetleg 3 kérdésre helyesen válaszolók közül senki nem tudott helyesen válaszolni erre a kérdésre.

Érdekes eredményeket kaphatunk a különböző kérdésekre adott lehetséges válaszok kombinációinak vizsgálatával. Megvizsgálhatjuk, hogy hány esetben adtak helyes választ például az $i k 4$, ik5 és $i k 9$ kérdésekre az ápolók, miközben hibásan válaszoltak a többi kérdésre. Mivel az eredeti ikl-ikll kérdés esetében a lehetséges válaszkombinációk száma rendkívül magas, a válaszmintázatok gyakoriságának elemzéséhez a 11 kérdésből 5 kérdéscsaládot alakítottunk ki, és az azokra adott válaszokat elemeztük. A kérdéscsaládokat az 1., 6. és 7. kérdésekből, a 2. és 5. kérdésekből, a 3. és 4. kérdésekbőll, a 8. és 10. kérdésekből, valamint a 9. és 1l. kérdésekből alakítottuk ki annak érdekében, hogy az összefüggő kérdések kerüljenek egy családba (5. táblázat).

5. táblázat | Ismeretekre vonatkozó kérdéscsoportok

\begin{tabular}{ll}
\hline Kérdéscsalád azonosítója & $\begin{array}{l}\text { Kérdéscsaládba tartozó kérdések } \\
\text { száma }\end{array}$ \\
\hline 1. ik_167 & $1+6+7$ \\
2. ik_25 & $2+5$ \\
3. ik_34 & $3+4$ \\
4. ik_810 & $8+10$ \\
5. ik_911 & $9+11$ \\
\hline
\end{tabular}


6. táblázat $\mid$ A helyes és a helytelen válaszok aránya a transzfúziós terápiával kapcsolatos kérdéscsaládokra kapott válaszok kapcsán

\begin{tabular}{lllll}
\hline $\begin{array}{l}\text { Kérdés- } \\
\text { családok }\end{array}$ & $\begin{array}{l}\text { Helytelen } \\
\text { válaszok } \\
\text { aránya }(0)\end{array}$ & $\begin{array}{l}\text { Helyes } \\
\text { válaszok } \\
\text { aránya }(1)\end{array}$ & Logit & $\begin{array}{l}\text { Esély- } \\
\text { hányados }\end{array}$ \\
\hline ik_167 & 0,7245 & 0,2755 & $-0,9669$ & 0,38 \\
ik_25 & 0,7884 & 0,2116 & $-1,3155$ & 0,27 \\
ik_34 & 0,7671 & 0,2329 & $-1,1921$ & 0,30 \\
ik_810 & 0,9300 & 0,0700 & $-2,5865$ & 0,075 \\
ik_911 & 0,7534 & 0,2466 & $-1,1170$ & 0,33 \\
\hline
\end{tabular}

Egy kérdéscsaládra akkor tekintettük a választ helyesnek, ha a családot alkotó valamennyi kérdésre helyes válasz érkezett. A 6. táblázat a helyes-hibás válaszok megoszlását mutatja be az 5 kérdéscsaládban. A kapott eredményekből kitûnik, hogy sajnos valamennyi kérdéscsalád kapcsán nagyobb arányú volt a helytelenül válaszolók aránya, mint a helyesen válaszolóké. A legroszszabb eredmény az ik_810 kérdéscsalád esetében született, ott a nem tudás mértéke $93 \%$ volt. A legjobb eredmény pedig az ik_167 kérdéscsalád kapcsán volt tapasztalható, a megkérdezettek 27,55\%-a válaszolt helyesen ezekre a kérdésekre.

A kérdéscsaládok esetében is megvizsgáltuk, hogy öszszesen hányra tudtak helyes választ adni a megkérdezett ápolók (7. táblázat). A táblázatban szemléltetett eredményeinkből látható, hogy 258 olyan ápoló volt, aki egyik kérdéscsaládra sem tudott helyesen válaszolni, és a csupán egy kérdéscsaládra helyesen válaszolók száma is meglehetósen magas (230 fö).

7. táblázat |A helyes választ adók száma kérdéscsaládonként

\begin{tabular}{llllllll}
\hline A gyakoriság összesített pontszáma kérdéscsaládonként & & \\
\hline $\begin{array}{l}\text { Helyesen } \\
\text { megválaszolt } \\
\text { kérdéscsoportok } \\
\text { darabszáma }\end{array}$ & 0 & 1 & 2 & 3 & 4 & 5 \\
$\begin{array}{l}\text { Helyes választ adók } \\
\text { száma }\end{array}$ & 258 fón & 230 fó & 99 fó & 42 fó & 3 fó & $15 f^{\prime \prime \prime}$ \\
\hline
\end{tabular}

A 3. ábra azt szemlélteti, hogy az egyes kérdéscsaládokra milyen arányban születtek helyes válaszok a helyesen megválaszolt kérdések számának függvényében. Az ábrán az látszik, hogy különböző összpontszámok esetében az 1-5 kérdéscsoportokra milyen arányban születtek helyes válaszok (például ik_167: 1., 6. és 7. kérdés összevonása). Látható, hogy az ik_167 vezeti a mezőnyt, a legnagyobb ismerethiány az $\overline{i k \_} 810$ esetében tapasztalható.

A 8. táblázat a különböző válaszmintázatok előfordulási gyakoriságát mutatja be. Az 1 -es számmal a tudást (helyes ismeretet), a 0 -val a nem tudást (helytelen isme-
8. táblázat | Válaszmintázatok előfordulási gyakoriságai

\begin{tabular}{|c|c|c|c|c|c|c|}
\hline Mintázatok & ik_167 & ik_25 & ik_34 & ik_810 & ik_911 & $\begin{array}{l}\text { Előfor- } \\
\text { dulás }\end{array}$ \\
\hline (1.) & 1 & 1 & 1 & 0 & 1 & 3 fó \\
\hline (2.) & 0 & 0 & 0 & 1 & 0 & 3 fó \\
\hline (3.) & 0 & 1 & 1 & 0 & 1 & 3 fó \\
\hline (4.) & 1 & 0 & 1 & 0 & 0 & 13 fó \\
\hline (5.) & 1 & 0 & 0 & 0 & 1 & 16 fó \\
\hline (6.) & 1 & 1 & 1 & 0 & 0 & 6 fó \\
\hline (7.) & 1 & 0 & 0 & 1 & 0 & 2 fó \\
\hline (8.) & 0 & 1 & 1 & 0 & 0 & 10 fó \\
\hline (9.) & 1 & 0 & 1 & 1 & 1 & 1 fó \\
\hline (10.) & 0 & 0 & 1 & 1 & 0 & 2 fó \\
\hline (11.) & 1 & 1 & 1 & 1 & 0 & 1 fó \\
\hline (12.) & 1 & 0 & 1 & 0 & 1 & 10 fó \\
\hline (13.) & 0 & 1 & 0 & 1 & 1 & 1 fó \\
\hline (14.) & 1 & 1 & 0 & 0 & 1 & 9 fó \\
\hline (15.) & 1 & 0 & 0 & 1 & 1 & 2 fó \\
\hline (16.) & 1 & 0 & 1 & 1 & 0 & 2 fó \\
\hline (17.) & 0 & 0 & 0 & 0 & 0 & $258 f^{\prime \prime}$ \\
\hline (18.) & 1 & 1 & 0 & 1 & 1 & 2 fó \\
\hline (19.) & 1 & 1 & 0 & 1 & 0 & 2 fó \\
\hline (20.) & 0 & 1 & 0 & 0 & 0 & 41 fó \\
\hline (21.) & 0 & 1 & 0 & 0 & 1 & 15 fó \\
\hline (22.) & 0 & 0 & 1 & 0 & 1 & 19 fó \\
\hline (23.) & 0 & 0 & 0 & 0 & 1 & 56 fó \\
\hline (24.) & 1 & 1 & 0 & 0 & 0 & 22 fó \\
\hline (25.) & 0 & 1 & 1 & 1 & 0 & 3 fó \\
\hline (26.) & 0 & 0 & 1 & 0 & 0 & 55 fó \\
\hline (27.) & 0 & 0 & 1 & 1 & 1 & 4 fó \\
\hline (28.) & 1 & 0 & 0 & 0 & 0 & 75 fó \\
\hline (29.) & 0 & 1 & 1 & 1 & 1 & 6 fó \\
\hline (30.) & 1 & 1 & 1 & 1 & 1 & $15 f^{\prime \prime}$ \\
\hline
\end{tabular}

retet) jelöltük. Az 5 kérdéscsoport esetében 30-féle mintázat fordult eló a válaszokban. Sajnos a leggyakoribb a $(0,0,0,0,0)$ mintázat az, amelyiknél valamennyi válasz hibás volt. Ezt követi az a 75 fös csoport, amelynek tagjai az ik_167 kérdéscsaládra helyes választ adtak, de a további négy kérdéscsoportnál már hibásan válaszoltak.

\section{A kérdésekre adott válaszok kapcsolatainak elemzése klaszteranalizissel}

A transzfúziós terápiával kapcsolatos ismeretek felmérésére irányuló kérdések kapcsán klaszteranalízist végeztünk. Azt vizsgáltuk, hogy mely kérdésekre születtek hasonló válaszok, azaz a különböző kérdésekre adott válaszok mennyire estek távol egymástól. 


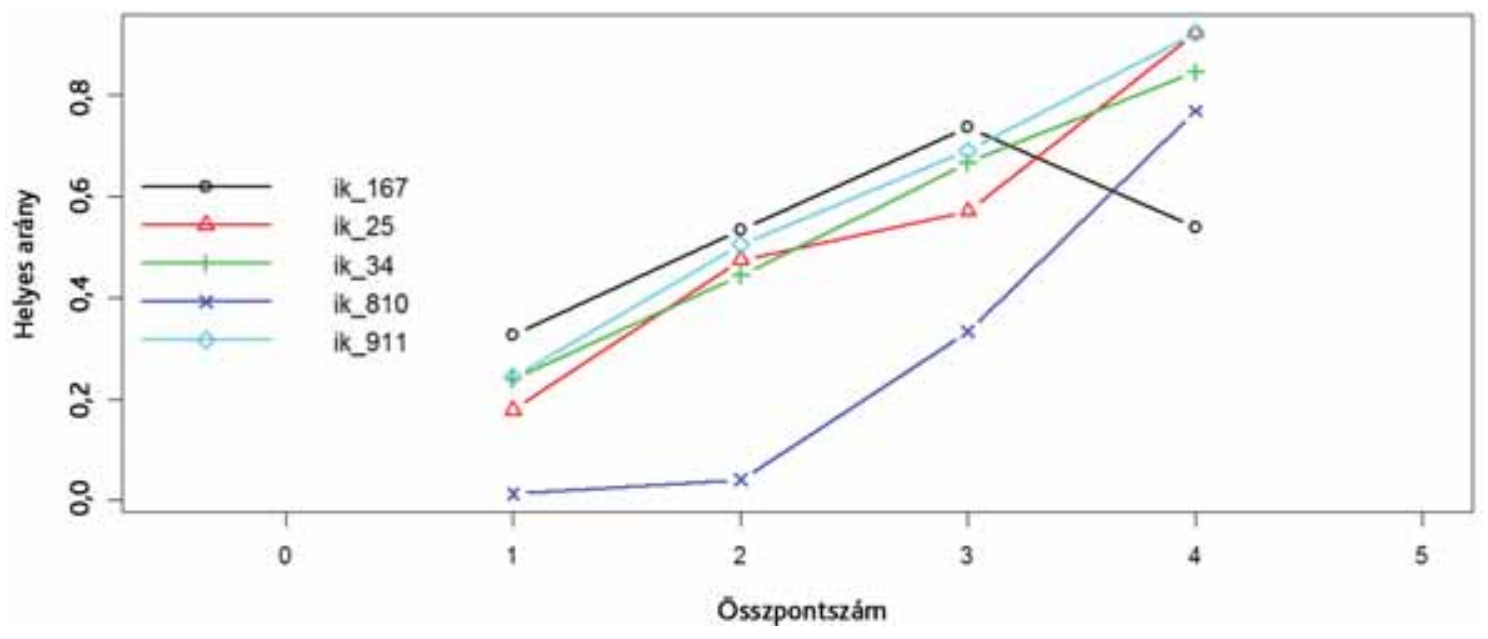

3. ábra | A helyes válaszok megoszlása kérdéscsoportonként a helyesen megválaszolt kérdéscsoportok számának függvényében

A hierarchikus klaszteranalízis eredményét a 4. ábrán mutatjuk be. A 4. ábrán látható, hogy az l. és a 6. kérdésre adott válaszok (ikl és ik6) alakultak hasonlóan, majd ehhez a klaszterhez csatlakoztak az (ik9), (ik4), valamint $i k 2$ kérdésekre adott válaszok. Az ezzel párhuzamos klaszterblokk az (ik8), (ik10), (ikl1), (ik5), (ik3) és (ik7) kérdésekboól épül fel. A dendrogram alapján a megkérdezettek tudásszintje (tudta vagy nem tudta a választ az egyes kérdésekre) természetesen nem megállapítható, csak az látszik, hogy akik helyesen válaszoltak az $i k l$ kérdésre, jellemzően tudták a jó választ az ik6 kérdésre is, vagy fordítva.

\section{Transzfúziós terápiával kapcsolatos ápolási kompetenciákra vonatkozó ismeretek (kk1-kk16) elemzése}

Általános hiba az ápolók körében az önálló és nem önálló funkciók keverése. Ennek oka, hogy az ápolási tevé-

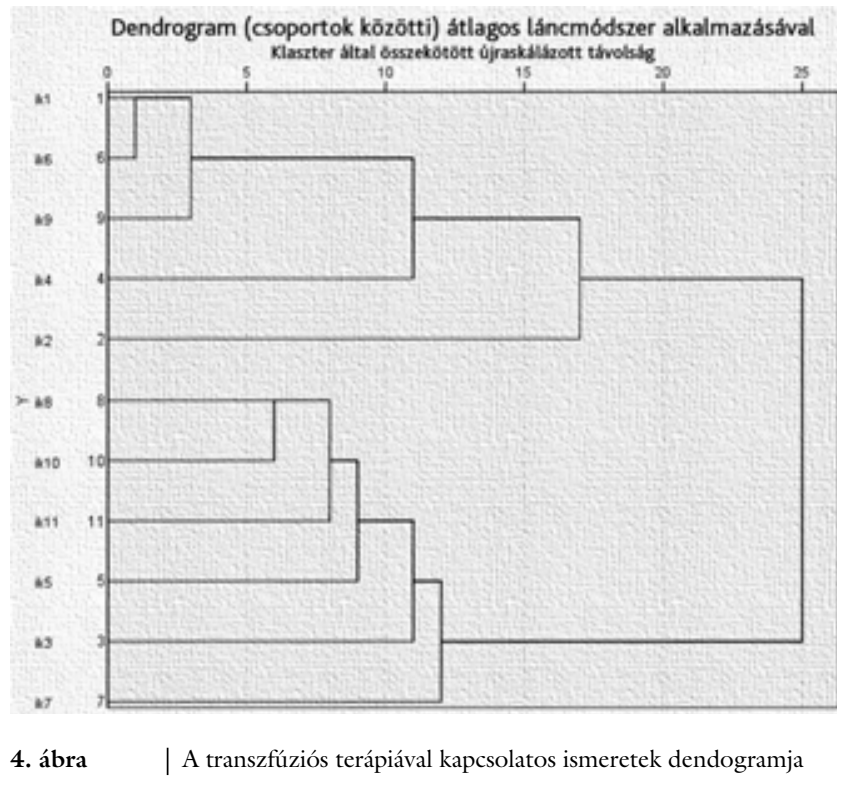

kenységeket nem az elrendelés, hanem a végrehajtás oldaláról közelítik meg, ezért a vérvételt, injekciózást, gyógyszerelést, EKG-készítést is az önálló funkciók közé sorolják csupán azért, mert önállóan hajtják végre. Valójában ezeket kizárólag orvosi utasításra, de önállóan és saját felelősségére végezheti az ápoló, tehát a nem önálló funkciók közé tartoznak [12]. A kérdőívben 16 ápolási tevékenységet soroltunk fel, amelyekkel kapcsolatban kértük a válaszadókat, határozzák meg, hogy azok mely ápolási funkcióba tartoznak. A 16 tevékenységbő́l a leginkább összetartozók alapján 8 párt alakítottunk ki, és ezeket a kkl-kkl6 (kk: képzési kompetencia) közötti azonosítókkal jelöltük (9. táblázat).

A 10. táblázat az egyes ápolási tevékenységek kapcsán meghatározott ápolási funkciókkal kapcsolatos válaszok megoszlását szemlélteti a helyes és a helytelen válaszok arányában. Legmagasabb arányban a kk11 ápolási tevékenység (ápolási dokumentáció vezetése) kapcsán, 98,33\%-

9. táblázat |Az ápolási funkciókkal kapcsolatos tevékenységek jelölése azonosítókkal

\begin{tabular}{l} 
Tevékenységek \\
\hline 1. Vérvétel $(\mathrm{kkl})$ \\
\end{tabular}

2. Kardinális tünetek 10. Injekciózás (kk10)

(vérnyomás, pulzus,

hőmérséklet, légzés) mérése (kk2)

3. Oxigén adása (kk3)

11. Ápolási dokumentáció vezetése (kkll)

4. Infúzió bekötése $(\mathrm{kk} 4)$

12. Gyógyszerelés (kkl2)

5. Transzfúzió bekötése (kk5)

13. Gyógyszeres fájdalomcsillapítás $(\mathrm{kk13})$

6. Vizelet-mintavétel 14. Vizit (kkl4)

laboratóriumi vizsgálatra (kk6)

7. EKG-készítés (kk7)

15. Vércsoport-meghatározás (kkl5)

8. Biológiai próba elvégzése (kk8)
16. Vérkészítmények melegítése (kkl6) 
10. táblázat | A helyes és a helytelen válaszok aránya az egyes ápolási tevékenységekre vonatkozó kérdéseknél

\begin{tabular}{llllc}
\hline $\begin{array}{l}\text { Ápolási } \\
\text { tevékeny- } \\
\text { ség száma }\end{array}$ & $\begin{array}{l}\text { Helytelen } \\
\text { válaszok } \\
\text { aránya }(0)\end{array}$ & $\begin{array}{l}\text { Helyes } \\
\text { válaszok } \\
\text { aránya }(1)\end{array}$ & Logit & $\begin{array}{l}\text { Esély- } \\
\text { hányados }\end{array}$ \\
\hline kk1 & 0,7093 & 0,2907 & $-0,8919$ & 0,41 \\
kk2 & 0,0335 & 0,9665 & 3,3626 & 28,85 \\
kk3 & 0,6134 & 0,3866 & $-0,4616$ & 0,630 \\
kk4 & 0,6499 & 0,3501 & $-0,6187$ & 0,538 \\
kk5 & 0,3577 & 0,6423 & 0,5854 & 1,795 \\
kk6 & 0,7717 & 0,2283 & $-1,2179$ & 0,295 \\
kk7 & 0,7869 & 0,2131 & $-1,3064$ & 0,270 \\
kk8 & 0,4521 & 0,5479 & 0,1924 & 1,212 \\
kk9 & 0,1096 & 0,8904 & 2,0949 & 8,124 \\
kk10 & 0,5936 & 0,4064 & $-0,3789$ & 0,684 \\
kk11 & 0,0167 & 0,9833 & 4,0729 & 58,880 \\
kk12 & 0,569 & 0,4307 & $-0,2788$ & 0,757 \\
kk13 & 0,4414 & 0,5586 & 0,2355 & 1,265 \\
kk14 & 0,2085 & 0,7915 & 1,3338 & 3,796 \\
kk15 & 0,4566 & 0,5434 & 0,1740 & 1,190 \\
kk16 & 0,8204 & 0,1796 & $-1,5190$ & 0,219 \\
\hline
\end{tabular}

11. táblázat | Egyes itemek nehézségi mutatói a kompetenciákra vonatkozóan

\begin{tabular}{lccr}
\hline Item & Becsült érték & Alsó CI & Felsó CI \\
\hline kk1 & 1,680 & 1,467 & 1,893 \\
kk2 & $-3,696$ & $-4,110$ & $-3,283$ \\
kk3 & 0,992 & 0,793 & 1,190 \\
kk4 & 1,243 & 1,040 & 1,447 \\
kk5 & $-0,559$ & $-0,747$ & $-0,371$ \\
kk6 & 2,186 & 1,960 & 2,413 \\
kk7 & 2,319 & 2,088 & 2,550 \\
kk8 & $-0,010$ & $-0,19$ & 0,177 \\
kk9 & $-2,368$ & $-2,623$ & $-2,113$ \\
kk10 & 0,860 & 0,664 & 1,057 \\
kk11 & $-4,418$ & $-4,987$ & $-3,849$ \\
kk12 & 0,703 & 0,509 & 0,896 \\
kk13 & $-0,072$ & $-0,259$ & 0,115 \\
kk14 & $-1,505$ & $-1,713$ & $-1,297$ \\
kk15 & 0,017 & $-0,170$ & 0,204 \\
kk16 & 2,626 & 2,385 & 2,868 \\
\hline
\end{tabular}

$\mathrm{CI}=($ confidence interval) megbízhatósági/konfidencia intervallum.

ban, a kk2 ápolási tevékenység (kardinális tünetek: vérnyomás, pulzus, hömérséklet, légzés mérése) kapcsán, 96,65\%-ban, valamint a $k k 9$ ápolási tevékenység (betegmegfigyelés) kapcsán, 89,04\%-ban tudták helyesen meghatározni az ápolási funkciót a megkérdezett ápolók. A legrosszabb eredmények a kk16 (vérkészitmény melegi-
12. táblázat | Kompetenciaszintek 8 klaszterben

\begin{tabular}{|c|c|c|}
\hline \multicolumn{3}{|l|}{ Tevékenységpárok } \\
\hline 1. Vérvétel (kkl) & $\Rightarrow$ & 4. Infúzió bekötése (kk4) \\
\hline $\begin{array}{l}\text { 2. Kardinális tünetek } \\
\text { (vérnyomás, pulzus, } \\
\text { hőmérséklet, légzés) } \\
\text { mérése (kk2) }\end{array}$ & $\Rightarrow$ & 9. Betegmegfigyelés (kk9) \\
\hline 3. Oxigén adása (kk3) & $\Rightarrow$ & 10. Injekciózás (kkl0) \\
\hline $\begin{array}{l}\text { 5. Transzfúzió bekötése } \\
(\mathrm{kk} 5)\end{array}$ & $\Rightarrow$ & $\begin{array}{l}\text { 8. Biológiai próba elvégzése } \\
(\mathrm{kk} 8)\end{array}$ \\
\hline $\begin{array}{l}\text { 6. Vizelet-mintavétel } \\
\text { laboratóriumi vizsgálatra } \\
(\mathrm{kk} 6)\end{array}$ & $\Rightarrow$ & 7. EKG-készítés (kk7) \\
\hline 12. Gyógyszerelés (kk12) & $\Rightarrow$ & $\begin{array}{l}\text { 13. Gyógyszeres } \\
\text { fájdalomcsillapítás }(\mathrm{kk13})\end{array}$ \\
\hline $\begin{array}{l}\text { 11. Ápolási dokumentáció } \\
\text { vezetése }(\mathrm{kkl} l)\end{array}$ & $\Rightarrow$ & 14. Vizit (kkl4) \\
\hline $\begin{array}{l}\text { 15. Vércsoport-meghatározás } \\
(\mathrm{kk} 15)\end{array}$ & $\Rightarrow$ & $\begin{array}{l}\text { 16. Vérkészítmények } \\
\text { melegítése (kk16) }\end{array}$ \\
\hline
\end{tabular}

tése - 82,04\%-ban téves meghatározás), a kk7 (EKG-készités-78,69\%-ban téves meghatározás) és a $k k 6$ (vizeletmintavétel laboratóriumi vizsgálatra - 77,17\%-ban téves meghatározás) kompetenciák esetében születtek.

A 11. táblázatban a kompetenciákra vonatkozó itemek nehézségi mutatóit foglaltuk össze. A kapott eredményeinkből látható, hogy a kkll ápolási tevékenység, valamint a $k k 2$ ápolási tevékenység kapcsán az ápolási funkciók meghatározása okozta a legkisebb problémát az ápolóknak, tehát ez a két item volt a legkönyebb. Míg a kk16 és a kk7 ápolási tevékenység kapcsán az ápolási funkciók meghatározása okozta a legnagyobb problémát, tehát ez a két item volt a legnehezebb.

$\mathrm{Az}$ 5. ábrán az egyes itemek karakterisztikus görbéjét tüntetjük fel, amely az elért összpontszám (logitskálára transzformált latent variable) függvényében a szóban forgó item helyes megválaszolásának valószínúségét ábrázolja a Rasch-modell alapján [11].

Ez esetben sem csak az egyes tevékenységek kapcsán, hanem a 16 ápolási tevékenységből összeállított 8 pár kapcsán is vizsgáltuk a kapott válaszok megoszlását a helyesen és a helytelenül meghatározott kompetenciák arányának függvényében. Az ápolási tevékenységeket a 12 . táblázatban látható módon párosítottuk. Itt is arra törekedtünk, hogy az egymással lehető legszorosabb összefüggésben lévő tevékenységek kerüljenek egy csoportba, a kórházi/klinikai gyakorlatból kiindulva.

A 13. táblázat a helyes/helytelen válaszok megoszlását mutatja be. A kapott eredményekból (13. táblázat) kitünik, hogy sajnos két tevékenységpár (kk_29 és kk_1114) kivételével az összes többi esetében nagyobb arányú volt a helytelenül válaszolók aránya, mint a helyesen válaszolóké. A legrosszabb eredmény a kk_1516 tevékenységpár (vércsoport meghatározása + vérkészitmény melegitése) esetében született, ott a nem tudás mértéke 


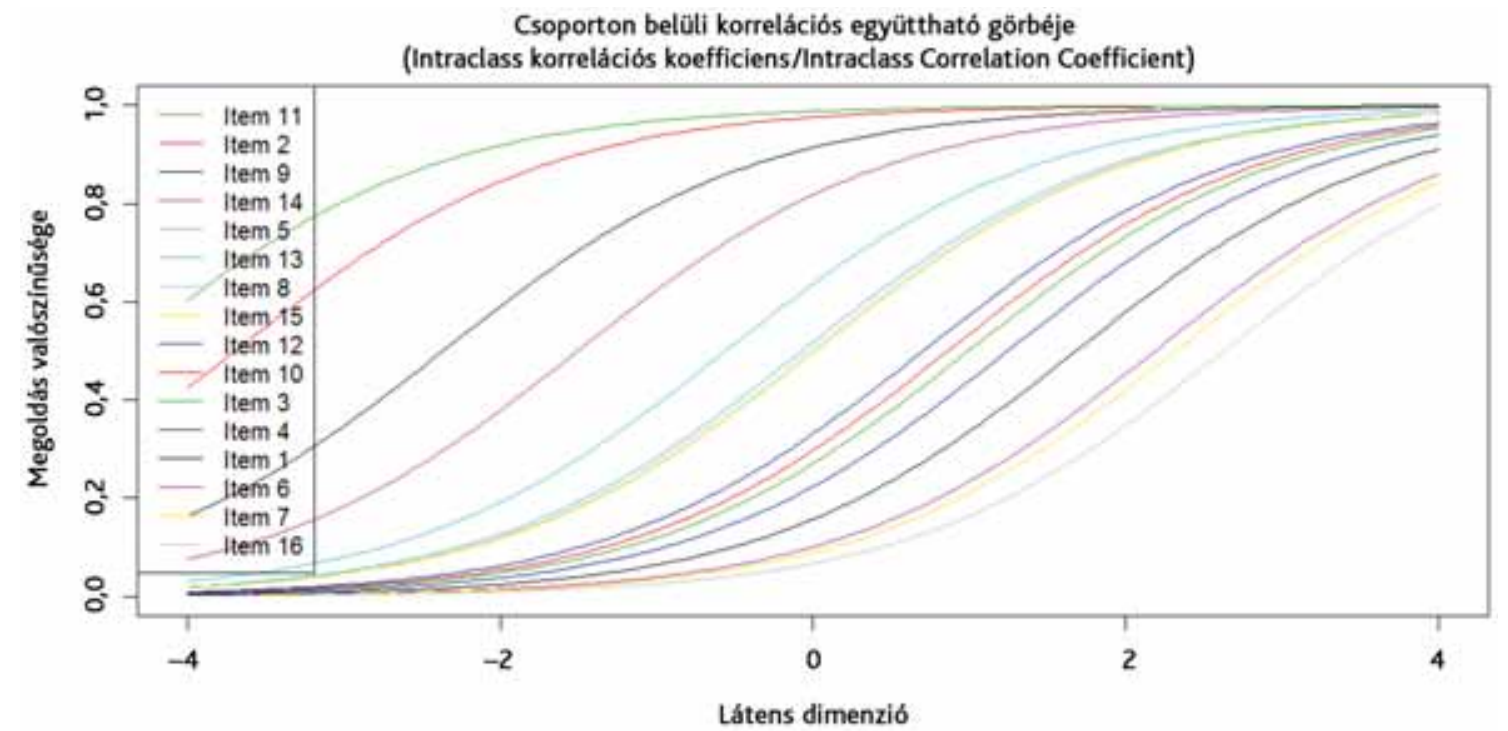

5. ábra

| Itemek karakterisztikus görbéje az egyparaméteres Rasch-modell alapján az ápolási kompetenciákra vonatkozó ismeretek esetében

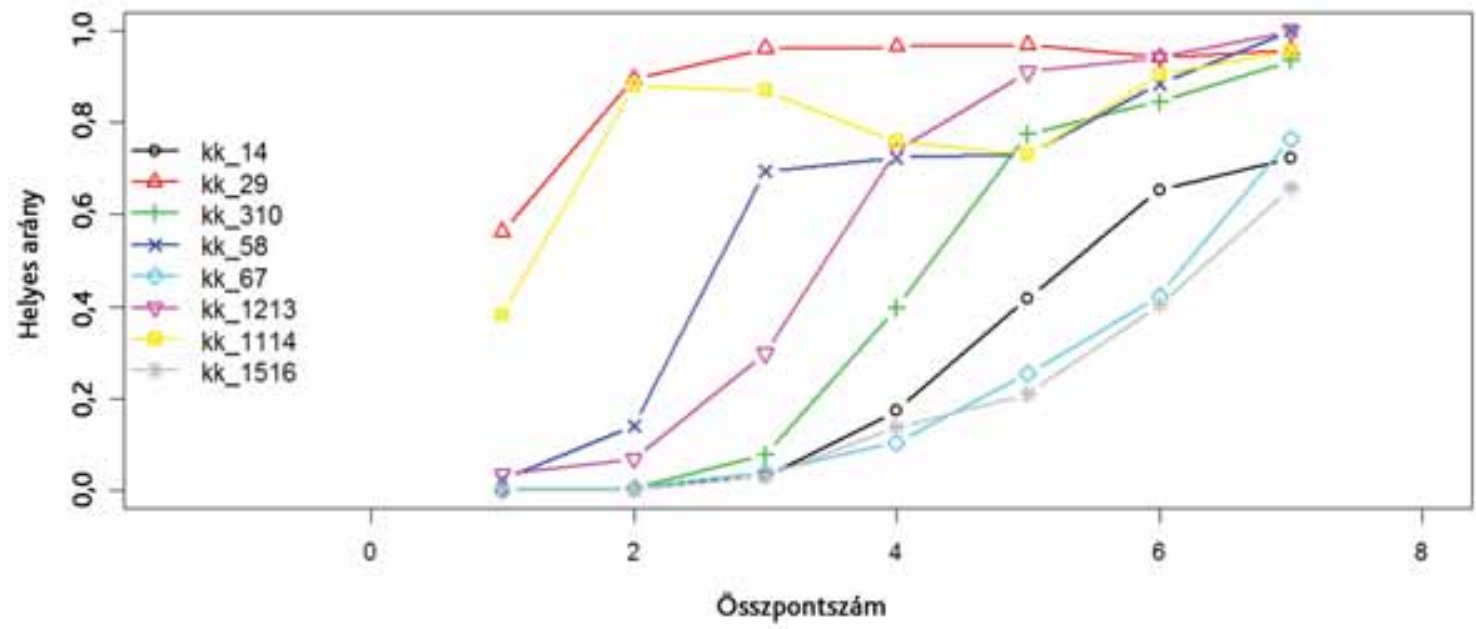

6. ábra $\mid$ A helyes válaszok megoszlása tevékenységpáronként a helyesen megválaszolt tevékenységpárok számának függvényében

13. táblázat |A helyes és a helytelen válaszok aránya az ápolói kompetenciákkal kapcsolatos kérdéscsaládoknál

\begin{tabular}{lllrl}
\hline $\begin{array}{l}\text { Tevékenység- } \\
\text { párok }\end{array}$ & $\begin{array}{l}\text { Helytelen } \\
\text { válaszok } \\
\text { aránya (0) }\end{array}$ & $\begin{array}{l}\text { Helyes } \\
\text { válaszok } \\
\text { aránya }(1)\end{array}$ & Logit & $\begin{array}{l}\text { Esély- } \\
\text { hányados }\end{array}$ \\
\hline kk_14 & 0,8174 & 0,1826 & $-1,4985$ & 0,2234 \\
kk_29 & 0,1279 & 0,8721 & 1,9201 & 6,818 \\
kk_310 & 0,7215 & 0,2785 & $-0,9517$ & 0,386 \\
kk_58 & 0,5236 & 0,4764 & $-0,0944$ & 0,910 \\
kk_67 & 0,8539 & 0,1461 & $-1,7654$ & 0,171 \\
kk_1213 & 0,5982 & 0,4018 & $-0,3979$ & 0,671 \\
kk_1114 & 0,2207 & 0,7793 & 1,2616 & 3,531 \\
kk_1516 & 0,8676 & 0,1324 & $-1,8797$ & 0,152 \\
\hline
\end{tabular}

$86,76 \%$ volt. A második legrosszabb pedig a kk_67 tevékenységpár (vizelet-mintavétel laboratóriumi vizsgálatra + EKG-készités) esetében, ahol a nem tudás mértéke 85,39\% volt. A legjobb eredmények a kk_29 tevékenységpár (kardinális tünetek: vérnyomás, pulzus, bömérséklet, légzés mérése + betegmegfigyelés - 87,21\% helyes válasz) és a kk_1114 tevékenységpár (ápolási dokumentáció vezetése + vizit - 77,93\% helyes válasz) kapcsán volt tapasztalható.

A tevékenységpárok kapcsán is vizsgáltuk azt, hogy az ápolási funkciók meghatározására feltett kérdéspároknál hányra tudtak helyes választ adni a megkérdezett ápolók (14. táblázat). A táblázatban látható, hogy 11 fó egyik ápolói tevékenységet sem tudta helyesen azonosítani, 
14. táblázat |A helyes választ adók száma tevékenységpáronként

\begin{tabular}{|c|c|c|c|c|c|c|c|c|c|}
\hline \multicolumn{10}{|c|}{ A gyakoriság összesített pontszáma tevékenységpáronként } \\
\hline $\begin{array}{l}\text { Helyesen megválaszolt } \\
\text { tevékenységpárok } \\
\text { darabszáma }\end{array}$ & 0 & 1 & 2 & 3 & 4 & 5 & 6 & 7 & 8 \\
\hline Helyes választ adók száma & $11 f^{\prime \prime}$ & 89 fó & 193 fö & 131 fó & 58 fó & 67 fö & 52 fö & 47 fó & $9 f^{\prime \prime}$ \\
\hline
\end{tabular}

15. táblázat | Válaszmintázatok az ápolási funkciók meghatározására szolgáló kérdéspárok esetén

\begin{tabular}{|c|c|c|c|c|c|c|c|c|c|}
\hline Varianciák & kk_14 & kk_29 & kk_310 & kk_58 & kk_67 & kk_1213 & kk_1114 & kk_15l6 & Előfordulás \\
\hline (23.) & 0 & 0 & 0 & 0 & 0 & 0 & 0 & 0 & 11 fö \\
\hline (53.) & 0 & 1 & 1 & 0 & 1 & 1 & 0 & 0 & 1 fó \\
\hline (58.) & 0 & 1 & 0 & 0 & 0 & 0 & 0 & 0 & 50 fó \\
\hline (69.) & 0 & 1 & 0 & 1 & 0 & 0 & 1 & 0 & 77 fó \\
\hline$(72)$. & 1 & 1 & 1 & 1 & 1 & 1 & 1 & 1 & 9 fö \\
\hline$(75)$. & 1 & 1 & 1 & 1 & 0 & 1 & 1 & 1 & 11 fó \\
\hline$(80)$. & 1 & 1 & 1 & 1 & 1 & 1 & 1 & 0 & 16 fó \\
\hline (86.) & 0 & 1 & 0 & 0 & 0 & 0 & 1 & 0 & 151 fó \\
\hline
\end{tabular}

1 tevékenységpár esetében az ápolási funkciót helyesen meghatározni tudó ápolók száma 89 fő volt, míg 2 tevékenységpár esetében 193 fó. 9 olyan ápoló volt a teljes mintában, aki mind a 8 tevékenységpárral kapcsolatban helyesen válaszolt.

A 8 tevékenységpár esetében 90-féle kombináció fordult elő a válaszokban. Ezek közül a leggyakrabban előforduló kombinációkat tüntettük fel a 15. táblázatban. A leggyakrabban (151 ápolónál) az a mintázat fordult elő, amelynél helyesen válaszoltak a kk_29 (kardinális tünetek: vérnyomás, pulzus, hömérséklet, légzés mérése + betegmegfigyelés) és a kk_1114 (ápolási dokumentáció ve-

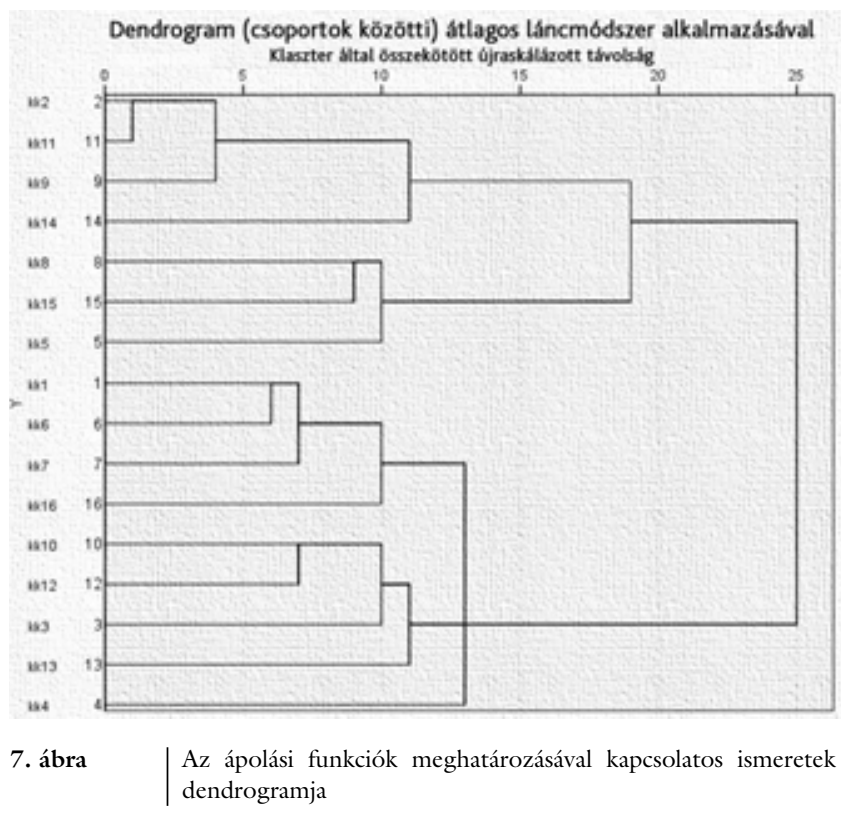

zetése + vizit) kérdéspárokra, és hibás választ adtak a többi kérdés esetében.

A 6. ábrán az látszik, hogy különböző összpontszámok esetében az 1-8 tevékenységpárra milyen arányban születtek helyes válaszok (például kk_14: 1. és 4. tevékenység összevonása) annak függvényében, hogy ki hány tevékenységpár kapcsán volt tisztában az ápolási funkcióval. Itt is látható, hogy a kk_29van az élen, a legnagyobb ismerethiány pedig a kk_1516 esetében tapasztalható.

Az ápolási funkciók (önálló, nem önálló, együttmúködő) meghatározásával kapcsolatos ismeretek felméréséhez feltett kérdések kapcsán szintén végeztünk klaszteranalízist, amelynek eredményét a 7 ábra mutatja. Ezen a 7. ábrán az látható, hogy a kk2 és kk11 mozogtak együtt, az általuk alkotott klaszter a $k k 9$ kérdéssel, ez az egység a kk14 kérdéssel, majd ez a blokk a $k k 8$ tevékenységgel. A felül látható nagy klaszterblokk a $k k 15$, majd $k k 5$ változókkal épült tovább. Azaz a következő ápolási tevékenységek kapcsán meghatározott kompetenciák alkotnak itt egy csoportot: kardinális tünetek: vérnyomás, pulzus, hömérséklet, légzés mérése és ápolási dokumentáció vezetése, a betegmegfigyelés, vizit és biológiai próba elvégzése, a vércsoport-meghatározás és transzfúzió bekötése.

A másik nagy részklasztert pedig a vérvétel, vizeletmintavétel laboratóriumi vizsgálatra, EKG-készités, vérkészitmények melegitése, injekciózás, gyógyszerelés, oxigén adása, gyógyszeres fájdalomcsillapitás és az infúzió bekötése alkották.

\section{Megbeszélés}

Modern tesztelméleti (IRT) eszközökkel vizsgáltuk a hazai ápolók transzfúziós terápiával kapcsolatos ismereteit, illetve az általunk rendszerezett ápolási tevékenységek 
kompetenciáinak meghatározását az ápolási funkciók alapján.

Az országos szintü felmérésünkhöz a modern, valószínûségi IRT-tesztelméletek közül a dichotóm adatok elemzésére alkalmas egyparaméteres matematikai Raschmodellt alkalmaztuk. A Rasch-modell segítségével az ápolók a kérdőív egyes kérdésein elért összpontszámát számoltuk ki a helyes, illetve a helytelen válaszok valószínüségének megadásával. A kutatás során képet kaptunk a transzfúziós terápiával kapcsolatos kérdéseinkre kapott helyes és hibás válaszok megoszlásáról, továbbá az ezekből számított logit- és esélyhányados-értékek alapján a helyes-hibás válaszadás valószínűségéről. Informálódhattunk arról, mely kérdéseinket válaszolták meg könynyen, melyeket nehezen a felmérésben részt vett ápolók [8].

A transzfúziós terápiával kapcsolatos ismeretekre vonatkozó kérdések közül a betegfelvilágosítási és -hozzájárulási nyilatkozatmintával és a választott vér beadása előtt is kötelező klinikai AB0- és RhD-vércsoport-meghatározással kapcsolatos kérdéseket válaszolták meg helyesen a legnagyobb arányban (2. táblázat). A transzfúzió előtt elvégzendő vizsgálatokra és biológiai próbára vonatkozó kérdések megválaszolása okozta a legnagyobb nehézséget (3. táblázat), ez utóbbiak esetében volt a legalacsonyabb a helyes válasz valószínúsége is (1.ábra). Klaszteranalízis segítségével két nagy kategóriát tudtunk elkülöníteni a transzfúziós terápiával kapcsolatos ismeretek felméréséhez használt kérdések kapcsán (4. ábra). Az ápolók a kérdések helyes megválaszolásában közepes teljesítményt nyújtottak, a legtöbben négy, öt, illetve hat kérdésre tudtak helyesen válaszolni a 11-ből (4. táblázat). A „Transzfúzió előtt elvégzendő vizsgálatok + biológiai próba" kérdéscsalád esetében a nemtudás mértéke 93\% volt (6. táblázat). Az egyes kérdéscsaládokra helyesen válaszolók száma alapján elmondható, hogy az ápolók inkább gyenge, mint közepes teljesítményt mutattak (7. táblázat). A mintánk több mint harmada (39,27\%-a) egyetlen kérdéscsoportra sem tudta a helyes választ (8. táblázat).

A transzfúziós terápia ápolási kompetenciáinak ismeretére vonatkozóan az ápolási dokumentáció vezetése, a kardinális tünetek (vérnyomás, pulzus, hőmérséklet, légzés) mérése, valamint a betegmegfigyelés esetében sikerült a legnagyobb arányban helyesen meghatározni az ápolási funkciókat (10. táblázat). Egyúttal ezen tevékenységek kapcsán okozta a legkisebb problémát az ápolási funkciók meghatározása az ápolóknak, tehát ezek az itemek voltak a legkönyebbek (11. táblázat). Összességében a helyesen válaszolók arányához képest nagyobb arányú volt a helytelenül válaszolók aránya a 16 ápolási tevékenységből összeállított 8 pár kapcsán (13. táblázat). A tevékenységpárok esetében az ápolási funkciókat helyesen meghatározni tudó ápolók teljsítménye gyengének mondható, leginkább csak 2-3 tevékenységpár esetében voltak erre képesek (14. táblázat). 9 ápoló tudta helyesen meghatározni valamennyi tevékenységpár esetében a hozzájuk tartozó ápolási funkciót (15. táblázat). A legnagyobb ismerethiány pedig a vércsoportmeghatározás és a vérkészítmények melegítése esetében volt tapasztalható (6. ábra). Szintén két nagy kategóriát tudtunk elkülöníteni klaszteranalízis segítségével az ápolási kompetenciákkal kapcsolatban (7. ábra).

Kutatásunk egyértelmúen bizonyította, hogy jelentős hiányosságok találhatók az ápolók transzfuziológiai ismereteiben, amivel foglalkoznunk kell. A vérbiztonság megőrzése az ápolók komoly szakmai, jogi és etikai felelőssége, tehát növelni kell a transzfúziós terápiában részt vevők szakmai ismereteit, készségeit, és biztosítani kell a megfelelő környezeti, tárgyi és személyi feltételeket. Csak magas tudásszinttel és szakmai felkészültséggel növelhető a transzfuziológia, illetve a betegek transzfúzió alatti és utáni biztonsága. A tudásszint objektív mérésének lehetősége a pedagógiában, így az ápolástan-oktatásban is kulcsfontosságú. Alkalmazása általában a pedagógiában is ritkának mondható, az egészségtudományok terén pedig különösen az. Mivel az ápolástudományi kutatások között nem találkoztunk ennek alkalmazásával, jelen kutatásunkat hiánypótlónak tekintjük, és figyelemfelhívásnak szánjuk.

Anyagi támogatás: A közlemény megírása, illetve a kapcsolódó kutatómunka anyagi támogatásban nem részesült.

Szerzői munkamegosztás: R. V.: Szakirodalmi rész feldolgozása, kutatási cél kidolgozása, a kézirat megszövegezése. Cs. M.: A módszer megválasztása, a kézirat megszövegezése, a végleges szöveg lektorálása. D. T.: A módszer megválasztása, IRT, klaszteranalízis kivitelezése, a kézirat megszövegezése, a végleges szöveg lektorálása. M. J.: Tanácsadás. A szerzők a kézirat végleges változatát elolvasták és jóváhagyták.

Érdekeltségek: A szerzőknek nincsenek érdekeltségeik.

A kézirat Rajki Veronika PhD-kutatásához kapcsolódik, amelynek témavezetője Dr. Mészáros Judit.

\section{Irodalom}

[1] Blood Transfusion Policy: Methodological letter of the Hungarian National Blood Transfusion Service. Unchanged reprint of the 2 nd edition with updated forms. [Transzfúziós Szabályzat: Az OVSZ módszertani levele, a 2. kiadás változatlan utánnyomása aktualizált formanyomtatványokkal.] Országos Vérellátó Szolgálat, Budapest, 2014. http://www.ovsz.hu/sites/ovsz.hu/ files/kepzes/szakmai_anyagok/transzfuzios_szabalyzat_2._kiadas/transzf-szab-verz_76_2_ujra_nyomas_jav_nyomtatv_ 20140912.pdf [Hungarian]

[2] Csóka, M., Vingender, I.: The methodology of the education with simulator. [A szimulátoros oktatás módszertana.] Nővér, 2010, 23(6), 22-39. [Hungarian]

[3] Csapó, B.: Achievement tests. In: Falis, I. (ed.): Introduction to the methodology of pedagogic research. [Tudásszintmérő tesztek. In: Falis, I. (szerk.): Bevezetés a pedagógiai kutatás mód- 
szereibe.] Múszaki Tankönyvkiadó, Budapest, 2000, 234-262. [Hungarian]

[4] Csapó, B.: Measurement and recognition of previously acquired knowledge. Final research study. [Az előzetesen megszerzett tudás mérése és elismerése. Kutatási zárótanulmány.] Nemzeti Felnőttképzési Intézet, Budapest, 2005. [Hungarian]

[5] Csapó, B.: The surface layers of school knowledge: what do the grades reflect? In: Csapó, B. (ed.): School knowledge. [Az iskolai tudás felszíni rétegei: mit tükröznek az osztályzatok? In: Csapó, B. (szerk.): Az iskolai tudás.] Osiris Kiadó, Budapest, 2002. [Hungarian]

[6] Molnár, Gy.: Examination of the application of knowledge with modern test theory (IRT) tools. [Az ismeretek alkalmazásának vizsgálata modern tesztelméleti (IRT) eszközökkel.] Magyar Pedagógia, 2003, 103(4), 423-446. [Hungarian]

[7] Xinming, A., Yiu-Fai, Y.: Item response theory: What it is and how you can use the IRT procedure to apply it, 2014. http:// support.sas.com/resources/papers/proceedings14/SAS3642014.pdf

[8] Molnár, Gy.: The possibility of objective assessment: the Rasch model. [Az objektív mérés lehetősége: a Rasch-modell.] Iskolakultúra, 2005, 15(3), 71-80. [Hungarian]

[9] Molnár, Gy.: The application of the Rasch model in the researches of social sciences. [A Rasch-modell alkalmazása a társadalom- tudományi kutatásokban.] Iskolakultúra, 2006, 16(12), 99-113. [Hungarian]

[10] Falus, I., Ollé, J.: Empirical research practice: Data processing and statistical analysis. [Az empirikus kutatások gyakorlata: adatfeldolgozás és statisztikai elemzés.] Felsőoktatási tankönyv. Nemzeti Tankönyvkiadó, Budapest, 2008. [Hungarian]

[11] Chong, H. Ү.: A simple guide to the item response theory (IRT) and Rasch modeling. Updated: August 20, 2013. http://www. creative-wisdom.com/computer/sas/IRT.pdf

[12] Csóka, M.: The implementation of the nursing activity, independent, dependent and interdependent functions of nursing care. In: Székely, A., Hollós, S., Csóka, M.: Clinical fundamentals of intensive care units. [ $\mathrm{Az}$ ápolási tevékenység végrehajtása, az ápolás önálló, nem önálló, és együttmúködő funkciói. In: Székely, A., Hollós, S., Csóka, M. (szerk.): Intenzív terápiás osztályok klinikai alapismeretei.] Semmelweis Egyetem, Egészségtudományi Kar, Budapest, 2013. [Hungarian]

(Rajki Veronika, Budapest, Vas utca 17., 1088 e-mail: rajki.veronika@se-etk.hu)

\section{A rendezvények és kongresszusok híranyagának leadása}

a lap megjelenése előtt legalább 40 nappal lehetséges, a 6 hetes nyomdai átfutás miatt. Kérjük megrendelőink szíves megértését.

A híranyagokat a következő címre kérjük: Orvosi Hetilap titkársága: Budai.Edit@akkrt.hu Akadémiai Kiadó Zrt. 